\title{
The pre-harvest foliar application influenced the flower quality and vase life of chrysanthemum cultivars
}

\begin{abstract}
The pre-harvest treatment of gibbrellic acid $\left(\mathrm{GA}_{3}\right)$ as foliar spray was applied to chrysanthemum cultivars in order to investigate its impact on flower quality, persistency on plant and vase life. The Randomized Complete Block Design (RCBD) with two factors factorial arrangement was used with foliar application of $\mathrm{GA}_{3}\left(0,50,100,150 \mathrm{mgL}^{-1}\right)$ sprayed on chrysanthemum cultivars (Rebbonet, Revert, Resomme and Magdalena) at button stage of flower buds. The foliar application of $\mathrm{GA}_{3}$ significantly influenced most of the growth parameters and enhanced the quality of flowers in chrysanthemum cultivars. However, the chrysanthemum plants when treated with gibbrellic acid $\left(\mathrm{GA}_{3}\right)$ at the rate of $100 \mathrm{mgL}$ ${ }^{1}$ resulted in maximum bud size $(2.29 \mathrm{~cm})$, flower size $(13.91 \mathrm{~cm})$, flower persistency on plant (51.14days), fresh flower weight (14.66g), dry flower weight $(6.03 \mathrm{~g})$ and vase life (37.15days). The cultivar Rebbonet showed the highest bud size $(2.28 \mathrm{~cm})$, flower size $(12.20 \mathrm{~cm})$, number of days to flower persistency $(47.00)$, fresh flower weight $(12.45 \mathrm{~g})$, dry flower weight $(5.08 \mathrm{~g})$, vase life (31.00days) and the least percent flower petal fading (9.69\%). The foliar application of gibbrellic acid at the rate of $100 \mathrm{mg} \mathrm{L}^{-1}$ significantly influenced the growth and quality flower production of chrysanthemum cultivar Rebbonet. It was concluded that the cultivar Rebonnet could be sprayed with foliar application of gibbrellic acid $\left(\mathrm{GA}_{3}\right)$ at the rate of $100 \mathrm{mg} \mathrm{L}^{-1}$ to obtain quality flowers under the agro climatic condition of Peshawar, Khyber Pakhtunkhwa-Pakistan.
\end{abstract}

Volume 2 Issue 4 - 2018

\author{
Muhammad Sajid,' Abdur Rab,' ljaz Ahmad \\ Khan, ${ }^{2}$ Ibadullah Jan, ${ }^{3}$ Noor ul Amin,' Abdul \\ Mateen,' Hamid Usman,' Mehboob Alam,' \\ Syed Tanveer Shah' \\ 'Department of Horticulture, The University of Agriculture, \\ Pakistan \\ ${ }^{2}$ Department of Weed Sciences, The University of Agriculture, \\ Pakistan \\ ${ }^{3}$ Department of Agriculture, University of SWABI, Pakistan
}

\begin{abstract}
Correspondence: Muhammad Sajid, Department of Horticulture, The University of Agriculture, Pakistan, Email msajid@aup.edu.pk; sajidhort@hotmail.com
\end{abstract}

Received: November 20, 2017 | Published: July 02, 2018

Key words: chyrsanthmum cultivars; gibbrellic acid; preharvest \& postharvest quality attributes and vase life

\section{Introduction}

Standard chrysanthemum (Dendranthema grandiflorum) commonly known as Gul-e-Daudi or mum flower, is a short-day flowering plant belonging to the largest family of plants Asteraceae. ${ }^{1}$ It is known as queen of flowers. It is popular ornamental plant in point of view as a cut flower, potted plant and landscape plant. ${ }^{2}$ Chrysanthemum is a major cut-flower, economically very important and placed second in the rank after rose in the world. ${ }^{3}$ Chrysanthemum is the most popular flowering plant all over the world as well as in Pakistan. In Pakistan, it starts flower blooming from the month of November and blooming reaches to its peak in the month of December. ${ }^{4}$ Chrysanthemum is facing various problems like poor growth; unreliable flower setting, insect-pests and diseases as well as no information are available regarding to planting time and sucker size. These conditions ultimately resulted in low yields with poor quality of flowers. ${ }^{5}$ It is one of the main perennial flowering plant grown in winter throughout the country. ${ }^{6}$ The effect and influence of growth regulator is evident even in minute quantity, as gibbrellic acid $\left(\mathrm{GA}_{3}\right)$ influences various growth parameters. ${ }^{7}$ Cut flowers are very sensitive, because their degradation starts soon after detachment from parent plant and senescence induced by ethylene. ${ }^{8}$ Gibbrellic acid $\left(\mathrm{GA}_{3}\right)$ is known to slow down leaf yellowing and control shedding of many famous cut flowers. ${ }^{9}$ Gibbrellin possesses stimulatory effect on various parameters of plant like germination, breaking dormancy, delaying senescence and ethylene activity as well as quality flower initiation. ${ }^{10}$ Post mutagenic application of GA3 significantly decreased the number of primary branches and pods plant ${ }^{-1}$ but stimulated secondary branches in chickpea. ${ }^{11}$ Application of gibbrellic acid $\left(\mathrm{GA}_{3}\right)$ to chrysanthemum flower improves the quality and durability of cut flowers by reducing senescence activity. ${ }^{12}$ Also gibbrellic acid $\left(\mathrm{GA}_{3}\right)$ plays a beneficial role in the longevity of many species of ornamental plants. ${ }^{13}$ As chrysanthemum is a famous winter flowering plant, the study was conducted to elaborate its ornamental and aesthetic value under the agro climatic conditions of Peshawar. To study the performance of best chrysanthemum cultivar under agro climatic condition of Peshawar for cut flowers and the response of pre-harvest treatment of gibbrellic acid $\left(\mathrm{GA}_{3}\right)$ on vase life of chrysanthemum flowers.

\section{Materials and methods}

The foliar application of gibbrellic acid $\left(\mathrm{GA}_{3}\right)$ at different concentrations $\left(0,50,100\right.$ and $\left.150 \mathrm{mgL}^{-1}\right)$ was sprayed at flower bud formation stage and when the buds were reached almost to button size. Healthy, insect, disease free and uniform sizes of already potted plants were selected, grown in pots of size $\left(20 \times 17 \mathrm{~cm}^{2}\right)$ having media consist of soil, silt and FYM in 1:1:1 ratio. The pots were watered gently through sprinkler as required. All necessary cultural practices were carried out throughout the experiment. As chrysanthemum is herbaceous plant and tender in nature therefore staking was also done accordingly. The extra flower buds were eliminated and only healthy and required buds were left for best flower development and production in each and every plant in pots. The cut flowers of chrysanthemum cultivars were kept in containers under (2\%) standard sugar solutions at Horticulture Department Khyber Pakhtunkhwa Agricultural University Peshawar.

\section{Pre harvest parameters}

\section{Bud size $(\mathrm{ml})$}

The bud sizes of five randomly taken chrysanthemum plants from all the treatments were measured at button stage by water displacement method after foliar application of gibbrellic acid $\left(\mathrm{GA}_{3}\right)$. 
The bud volume was then calculated as:

Bud volume $=$ final volume reading - initial volume reading

\section{Days to flower opening}

Number of days to flower opening was counted from the date of foliar application up to the date of full opening of five randomly taken flowers from all the treatments in each replication.

Flower size (cm): Flower size was measured with the help of measuring tape of five randomly taken flowers from all the treatments in each replication.

\section{Number of days to flower persistency}

The flower persistency on plants of five randomly taken flowers from all the treatments was examined till the fading of flowers and days was counted and recorded.

\section{Postharvest parameter}

\section{Fresh flower weight (g)}

Five randomly taken fully opened flowers from all the treatments were weighed with the help of electronic balance and recorded the fresh flower weight.

\section{Dry flower weight (g)}

Five randomly taken flowers from all the treatments were kept in oven at $60^{\circ} \mathrm{C}$ till complete drying of flowers and weighed with electronic balance and recorded the dry flower weight.

\section{Percent flower petal fading (\%)}

Fading of flower starts when the petals losses their decorative value and color. Five randomly taken flowers from all the treatments faded vase ${ }^{-1}$ were counted and percentage was calculated.

\section{Vase life (days)}

Longevity refers to the average time of a cut flower taken at full boom in vase of sugar solution till loss of decorative value. Five randomly taken flowers and vase life was recorded from all the treatments by counting number of days from the time, when the cut flowers were kept in vase till the flowers loss their decorative value after complete opening or shedding of petals.

\section{Statistical analysis}

The data was analyzed statistically using MSTATC software (Michigan State University, USA). ANOVA and least significance difference techniques were applied in order to see any difference among the different treatments regarding various parameters. ${ }^{14}$

\section{Results and discussion}

\section{Bud size ( $\mathrm{ml})$}

From the mean table it is cleared that chrysanthemum cultivars and foliar application of gibbrellic acid $\left(\mathrm{GA}_{3}\right)$ had a significant response to bud size $(\mathrm{ml})$ whereas their interaction had a non significant affect on the bud size of chrysanthemum (Table 1). A significant difference was observed for bud size of chrysanthemum cultivars. However, the chrysanthemum cultivar Rebonnet had the bigger bud size $(2.28 \mathrm{ml})$ followed by cultivars Magdalena $(2.25 \mathrm{ml})$ and
Resomee $(2.23 \mathrm{ml})$ respectively, which were at par with each other. While the cultivar Revert had the smallest bud size of $2.17 \mathrm{ml}$. The foliar application of gibbrellic acid $\left(\mathrm{GA}_{3}\right)$ significantly increased the bud size of chrysanthemum cultivars as compared to control treatment. The highest bud size $(2.29 \mathrm{ml})$ was recorded in plants, received foliar application of gibbrellic acid $\left(\mathrm{GA}_{3}\right)$ at the rate of $100 \mathrm{mg} \mathrm{L}^{-1}$, followed by $2.25 \mathrm{ml}$ and $2.22 \mathrm{ml}$ in plants received foliar application of gibbrellic acid $\left(\mathrm{GA}_{3}\right)$ at the rate of $150 \mathrm{mgL}^{-1}$ and $50 \mathrm{mgL}^{-1}$ respectively. The smallest bud size $(2.17 \mathrm{ml})$ was recorded in control treatment. The results regarding bud size of cultivar Rebonnet is in line with Liu et al., ${ }^{2}$ who argued that expansion in bud size of chrysanthemum was perhaps due to the activity of biologically active compounds like chlorogenic acid which promoted swelling of buds. A significant variation in bud size of chrysanthemum cultivar might be due to the genetic variability observed in different cultivars. The foliar application of gibbrellic acid $\left(\mathrm{GA}_{3}\right)$ increased/stimulated the synthesis of auxin in apical portion of the plant which caused cell elongation by rapid multiplications of cells in that particular region which ultimately increased the bud size of the chrysanthemum plant. The findings of present experiment are also in agreement with the results of Arun et al., ${ }^{15}$ who reported that the foliar application of gibbrellic acid $\left(\mathrm{GA}_{3}\right)$ significantly promoted the length of floral buds in rose cultivar First Red. Dorajeerao \& Mokashi $^{16}$ also reported a significant increased in the vegetative and reproductive attributes of chrysanthemum cultivar by the foliar application of gibbrellic acid $\left(\mathrm{GA}_{3}\right)$ at the rate of 100 and $150 \mathrm{mgL}^{-1}$. The highest yield and quality characteristics of Rosa hybrida significantly increased by increasing the gibbrellic acid $\left(\mathrm{GA}_{3}\right)$ concentrations from $150 \mathrm{mgL}^{-117}$

\section{Flower opening}

The scrutiny of the results showed that the numbers of days to flower opening was significantly affected by the application of various levels of gibbrellic acid $\left(\mathrm{GA}_{3}\right)$ as foliar spray. While the chrysanthemum cultivars and its interaction with foliar application of gibbrellic acid $\left(\mathrm{GA}_{3}\right)$ had a non significant effect on number of days to flower opening of chrysanthemum. The data in Table 1 indicated that number of days to flower opening is significantly influenced by different levels of foliar application of gibbrellic acid $\left(\mathrm{GA}_{3}\right)$. However the number of days to flower opening (30.95) was noted in control plants, followed by 28.72 and 28.63 in plants treated with 50 and $150 \mathrm{mgL}^{-1}$ of foliar application of gibbrellic acid $\left(\mathrm{GA}_{3}\right)$ respectively. Which were statistically at par with each other. The least days to flower opening (23.03) was observed in plants treated with foliar application of gibbrellic acid $\left(\mathrm{GA}_{3}\right)$ at the rate of $100 \mathrm{mgL}^{-1}$. A significant variation was observed on number of days to flower opening by foliar application of gibbrellic acid $\left(\mathrm{GA}_{3}\right)$ The reason for the early flower opening might be due to stimulatory role of gibbrellic acid $\left(\mathrm{GA}_{3}\right)$ which acts as bioactive promoter in the opening of flower and fruit. ${ }^{18}$ As clear from the results of present research that optimum dose of foliar application of gibbrellic acid $\left(\mathrm{GA}_{3}\right)$ induced early flowering in chrysanthemum. The results are in similarity with the findings of Blazquez et al., ${ }^{19}$ who observed that gibbrellic acid $\left(\mathrm{GA}_{3}\right)$ application stimulated early flowering in short day plant of Arabidopsis. It was cleared from the experiment that gibbrellic acid $\left(\mathrm{GA}_{3}\right)$ imparted pronounced effect in the opening of quality flower which is in accordance with present findings on flower opening of chrysanthemum. Similar results were also observed by Paroussi et al., ${ }^{20}$ observed early flower maturity in strawberry by the use of gibbrellic acid $\left(\mathrm{GA}_{3}\right)$. Endogenous gibbrellic acid $\left(\mathrm{GA}_{3}\right)$ plays significant role in the induction and maturity of flower and inflorescence of chrysanthemum. ${ }^{21}$ 
Table I Flower bud size $(\mathrm{ml})$, flower opening, flower size $(\mathrm{cm})$ of chrysanthemum cultivars as affected by gibbrellic acid (GA $\left.{ }_{3}\right)$

\begin{tabular}{llll}
\hline Parameters & Flower bud size $(\mathbf{m l})$ & Number of days to flower opening & Flower size $(\mathbf{c m})$ \\
\hline Cultivars & & & \\
Rebonnet & $2.28 \mathrm{a}$ & 25.86 & $12.20 \mathrm{a}$ \\
Revert & $2.17 \mathrm{~b}$ & 28.48 & $11.44 \mathrm{~b}$ \\
Resomee & $2.23 \mathrm{ab}$ & $28.6 \mathrm{I}$ & $1 \mathrm{I} .80 \mathrm{ab}$ \\
Magdalena & $2.25 \mathrm{a}$ & 28.38 & $11.9 \mathrm{I} \mathrm{ab}$ \\
LSD at $\alpha 0.05$ & 0.07 & $\mathrm{NS}$ & 0.52 \\
Gibbrellic acid concentration (mg L-I) & & \\
Control & $2.17 \mathrm{~b}$ & $30.95 \mathrm{a}$ & $9.50 \mathrm{~d}$ \\
50 & $2.22 \mathrm{ab}$ & $28.72 \mathrm{a}$ & $11.65 \mathrm{c}$ \\
I00 & $2.29 \mathrm{a}$ & $23.03 \mathrm{~b}$ & $13.9 \mathrm{I} \mathrm{a}$ \\
I50 & $28.63 \mathrm{a}$ & $12.28 \mathrm{~b}$ \\
LSD at $\alpha 0.05$ & 0.07 & 2.6 & 0.52 \\
Significance Level & Interaction (cultivars $\times$ GA) & & \\
C $\times$ G & NS & NS & $\mathrm{NS}$ \\
\hline
\end{tabular}

Means followed by the same letter (s) do not differ significantly from one another at $5 \%$ probability level, using LSD test.

\section{Flower size (cm)}

The mean data table showed that foliar application of gibbrellic acid $\left(\mathrm{GA}_{3}\right)$ and chrysanthemum cultivars showed a significant effect on flower size. While the interaction of foliar application of gibbrellic acid $\left(\mathrm{GA}_{3}\right.$ ) and chrysanthemum cultivars had a non significant effect on flower size of chrysanthemum (Table 1). The mean table for flower size of different chrysanthemum cultivars showed the that maximum flower size $(12.20 \mathrm{~cm})$ was recorded for cultivar Rebonnet, followed by cultivar Magdalena $(11.91 \mathrm{~cm})$ and Resomee $(11.80 \mathrm{~cm})$ respectively, which showed a non significant differences. Whereas the minimum flower size $(11.44 \mathrm{~cm})$ was recorded in cultivar Revert of chrysanthemum. The flower size of chrysanthemum cultivars was significantly influenced by the foliar application of gibbrellic acid $\left(\mathrm{GA}_{3}\right)$ levels. The highest flower size $(13.91 \mathrm{~cm})$ was recorded in plants, treated with $100 \mathrm{mgL}^{-1}$ foliar application of gibbrellic acid $\left(\mathrm{GA}_{3}\right)$, followed by $12.28 \mathrm{~cm}$ in plants received $150 \mathrm{mgL}^{-1}$ of foliar application of gibbrellic acid $\left(\mathrm{GA}_{3}\right)$. The smallest flower size $(9.50 \mathrm{~cm})$ was observed in control treatment. The increase in the size of the flower in chrysanthemum may be due to the environmental factors including photoperiod, light quality and intensity. The luxuriant growth and attainment in flower size in term of diameter may be due to the genetic potential of various chrysanthemum cultivars used in the present experiment. The characteristic of gibbrellic acid (GA $)$, which might have trigerred the cell multiplication rate in the bud region which increased the plant ability to perform better photosynthesis process and to acquire more nutrients. The increment in inflorescence diameter from the study coincide with the results of Rakesh et al., ${ }^{22}$ who obtained similar results from inflorescence diameter of chrysanthemum by the foliar application of gibbrellic acid $\left(\mathrm{GA}_{3}\right)$. According to Madhumita \& Paswan $^{23}$ gibbrellic acid (GA $)$ perhaps caused elongation in the cells of inflorescence which eventually resulted in bigger flower diameter of chrysanthemum. Maximos et al., ${ }^{24}$ also observed a significant effect in growth and diameter of date fruits by the use of foliar application of gibbrellic acid $\left(\mathrm{GA}_{3}\right)$.

\section{Number of days to flower persistency}

The perusal of the results showed that the foliar application of gibbrellic acid ( $\left.\mathrm{GA}_{3}\right)$, chrysanthemum cultivars and their interaction had a significant effect on flower persistency on plant (Table 2). The mean value of number of days to flower persistency for different chrysanthemum cultivars indicated that more number of days to flower persistency (46.93) was recorded for the cultivar Rebonnet, followed by cultivar Magdalena (45.86). Whereas the lowest numbers of days to flower persistency (44.46) was recorded for cultivar Resomee. The number of days to flower persistency is significantly influenced by different levels of foliar application of gibbrellic acid $\left(\mathrm{GA}_{3}\right)$. The maximum number of days to flower persistency (51.14) was observed in plants, sprayed with foliar application of gibbrellic acid $\left(\mathrm{GA}_{3}\right)$ at the rate of $100 \mathrm{mgL}^{-1}$, followed by 45.05 days in plants treated with foliar application of gibbrellic acid $\left(\mathrm{GA}_{3}\right)$ at the rate of $150 \mathrm{mgL}^{-1}$. The least number of days to flower persistency (41.88) was recorded in plants grown under control conditions. The number of days to flower persistency was significantly affected by the interaction of chrysanthemum cultivars and the foliar application of gibbrellic acid $\left(\mathrm{GA}_{3}\right)$ sprayed. The highest number of days to flower persistency (52.53) was recorded in cultivar Rebonnet, sprayed with $100 \mathrm{mgL}^{-1}$ foliar application of gibbrellic acid $\left(\mathrm{GA}_{3}\right)$ solution. Whereas the least number of days to flower persistency (41.00) was noted in cultivar Resomee grown under control treatment (Figure 1). The presence of flowers for long time on chrysanthemum cultivar Rebonnet might be due to the genetic characteristic of each cultivar and some environmental factor played a vital role in the elongation 
of flower persistency on plant. Ma et al., ${ }^{25}$ found similar results from chrysanthemum cultivar trial and established that regulation and lengthy stay of chrysanthemum flower was probably due to regulation by genetic, light condition and irradiation. The persistency of flower on chrysanthemum plant might be due to delaying of the leaf and petals senescence by the application of exogenous gibbrellic acid $\left(\mathrm{GA}_{3}\right)$ which ultimately retarded the concentration of auxin and ethylene activity. ${ }^{26}$ The persistency of flower of chrysanthemum showed a positive response to foliar application of gibbrellic acid $\left(\mathrm{GA}_{3}\right)$ and its various levels. According to Halevy \& Mayak ${ }^{27}$ the growth promoters like gibbrellin and cytokinin may stop the formation of flower degradation agents or growth retardants. Our results are analogy with Cowan et al., ${ }^{28}$ who stated that gibbrellic acid $\left(\mathrm{GA}_{3}\right)$ changed the carbohydrate status and increased the sugar accumulation by providing defense mechanism against senescence and played a significant role in flower persistency on plant.

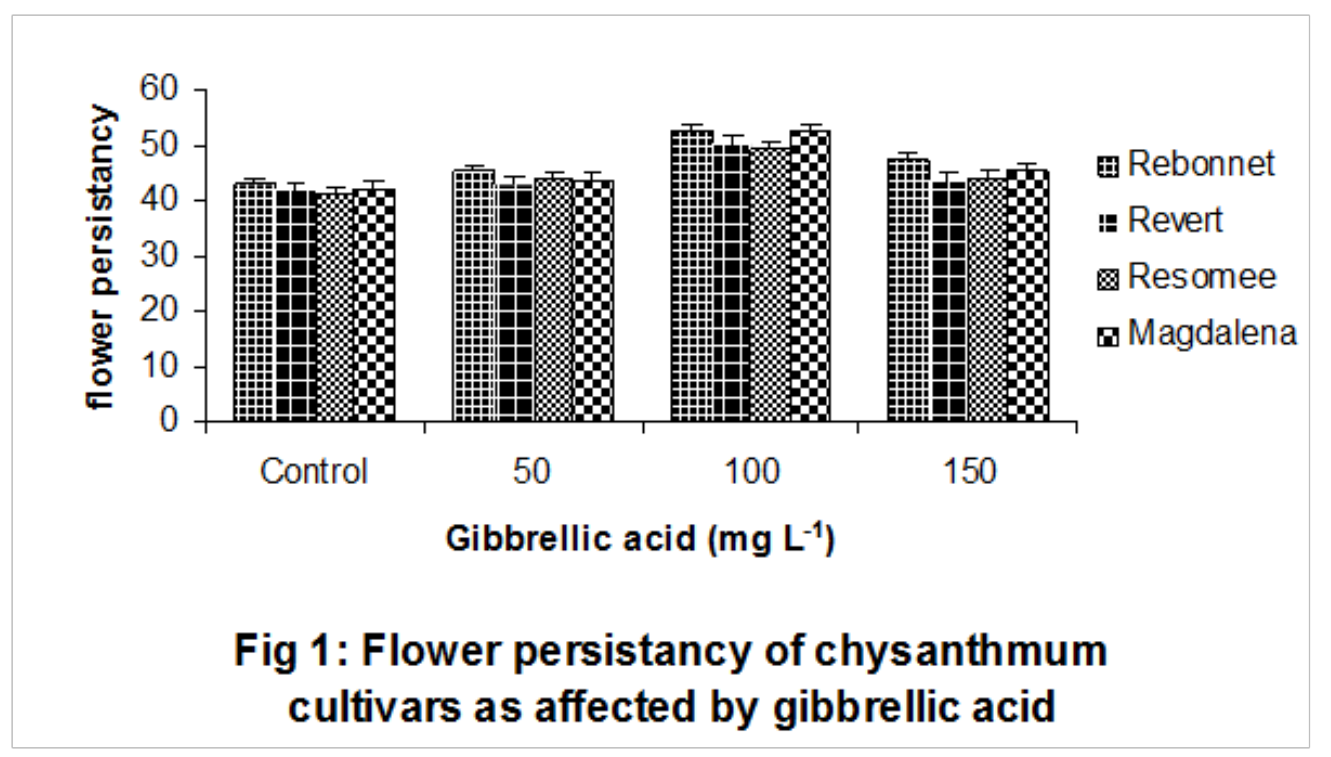

Figure I Flower persistency of chrysanthemum cultivars as affected by gibbrellic acid.

\section{Fresh flower weight (g)}

It is clear from the mean table that foliar application of gibbrellic acid $\left(\mathrm{GA}_{3}\right)$, cultivars and their interaction had a significant effect on the fresh flower weight of chrysanthemum (Table $2 \&$ Figure 2). There was a significant variation for fresh flower weight $(\mathrm{g})$ among different chrysanthemum cultivars. The cultivar Rebonnet showed the highest value $(12.45 \mathrm{~g})$ for fresh flower weight followed by cultivar Magdalena with $11.26 \mathrm{~g}$. which was at par with each other. Whereas, the lowest fresh flower weight $(5.86 \mathrm{~g})$ was recorded for the cultivar Revert. The fresh flower weight was significantly accelerated by the foliar application of gibbrellic acid $\left(\mathrm{GA}_{3}\right)$ at various levels. The highest value for fresh flower weight $(14.66 \mathrm{~g})$ was noted in plants treated with foliar application of gibbrellic acid $\left(\mathrm{GA}_{3}\right)$ at the rate of $100 \mathrm{mgL}^{-1}$, followed by $9.17 \mathrm{~g}$ in plants treated with $50 \mathrm{mgL}^{-1}$ of foliar application of gibbrellic acid $\left(\mathrm{GA}_{3}\right)$ The lowest fresh flower weight $(7.29 \mathrm{~g})$ was obtained in plants grown under control treatment. The increase in the fresh flower weight of chrysanthemum cultivars may be due to the genetic superiority and photosynthetic activity which promoted the accumulation of rich mineral along with required amount of water and thus had increased the fresh weight. The result of cultivar Rebonnet is consistent with ${ }^{29}$ that photosynthetic activity might have triggered $\mathrm{CO}_{2}$ assimilation to produce more carbohydrates and starch along with less transpiration resulted in increase of fresh flower weight in chrysanthemum. The fresh flower weight increased with increasing the foliar application of gibbrellic acid $\left(\mathrm{GA}_{3}\right)$ concentrations up to optimum level. It may be due to physiological and photosynthetic activity which made available the required amount of essential elements in the promotion of inflorescence fresh weight. The result of fresh flower weight of inflorescence is in harmony with the results of Aziz et al., ${ }^{30}$ who obtained a significant increased in fresh weight of date fruits with foliar application of gibbrellic acid $\left(\mathrm{GA}_{3}\right)$. The gradual increase of foliar application of gibbrellic acid $\left(\mathrm{GA}_{3}\right)$ at different levels initiated and assimilated elements essential may caused increase in the fresh weight of inflorescence. Kumar \& Singh $^{31}$ reported that the growth regulator enhanced the performance of seasonal flowers of carnation which is in correspondence with the findings of present research. The foliar application of gibbrellic acid $\left(\mathrm{GA}_{3}\right)$ significantly increased the weight of carnation flower. ${ }^{32}$

\section{Dry flower weight (g)}

Foliar application of gibbrellic acid $\left(\mathrm{GA}_{3}\right)$, chrysanthemum cultivars and their interaction had a significant effect on dry flower weight (Table 2). The cultivar Rebonnet indicated the highest dry flower weight $(5.08 \mathrm{~g})$ followed by cultivars Magdalena and Resomee with $4.84 \mathrm{~g}$ and $4.76 \mathrm{~g}$ respectively, however the variation among these cultivar was non significant. The lowest dry flower weight $(2.24 \mathrm{~g})$ was observed in cultivar Revert. The foliar application of gibbrellic acid $\left(\mathrm{GA}_{3}\right)$ significantly influenced the dry flower weight of chrysanthemum cultivars. The foliar application of gibbrellic acid $\left(\mathrm{GA}_{3}\right)$ when sprayed at the concentration of $100 \mathrm{mgL}^{-1}$ gave the highest dry flower weight $(6.03 \mathrm{~g})$. While the dry flower weight $(2.30 \mathrm{~g})$ was observed in the untreated plants of chrysanthemum. The dry flower weight was significantly affected by the interaction of chrysanthemum cultivars and the foliar application of gibbrellic acid 
$\left(\mathrm{GA}_{3}\right)$. The highest dry flower weight $(6.61 \mathrm{~g})$ was recorded in cultivar Rebonnet, treated with $150 \mathrm{mgL}^{-1}$ foliar application of gibbrellic acid $\left(\mathrm{GA}_{3}\right)$. Whereas the lowest flowers dry weight $(1.49 \mathrm{~g})$ was observed in cultivar Revert grown under control condition (Figure $3)$. The increase in the dry flower weight of cultivar Rebonnet may be correlated to the increased fresh of the same cultivar along with more accumulation of biomass from carbon compounds sucrose and fructose which ultimately resulted in more dry weight after drying. The increase in dry flower weight may be attributed to the fact that dry matter contents present in excessive amount by receiving high dose of foliar application of gibbrellic acid $\left(\mathrm{GA}_{3}\right)$. The dry weight of inflorescence is same with the findings of El-Hodairi et al. ${ }^{33}$ who observed the increment in the dry weight of date fruit. The reason for the dry weight perhaps is that time of blooming and inflorescence mature early and attained complete flower cycle due to which it might have promoted the dry weight. The present findings are in accordance with Ambad \& $\mathrm{Kadam}^{34}$ who reported that the biomass of dry flower of pyrethrum might have increased due to complete physiological maturity of pyrethrum flower.

Table 2 Flower persistency, fresh flower weight $(\mathrm{g})$, dry flower weight $(\mathrm{g})$ of chrysanthemum cultivars as affected by gibbrellic acid $\left(\mathrm{GA}_{3}\right)$

\begin{tabular}{llll}
\hline Parameters & Number of days for flower persistency on plant & Fresh flower weight (g) & Dry flower weight (g) \\
\hline Cultivars & & & \\
Rebonnet & $46.93 \mathrm{a}$ & $12.45 \mathrm{a}$ & $5.08 \mathrm{a}$ \\
Revert & $44.7 \mathrm{I} \mathrm{c}$ & $5.86 \mathrm{c}$ & $2.24 \mathrm{~b}$ \\
Resomee & $44.46 \mathrm{c}$ & $10.58 \mathrm{~b}$ & $4.76 \mathrm{a}$ \\
Magdalena & $45.86 \mathrm{~b}$ & $11.26 \mathrm{ab}$ & $4.84 \mathrm{a}$ \\
LSD at $\alpha 0.05$ & 0.66 & 1.66 & 0.92 \\
Gibbrellic acid concentration (mg L-1) & & \\
Control & $41.88 \mathrm{~d}$ & $7.29 \mathrm{c}$ & $2.30 \mathrm{c}$ \\
50 & $43.88 \mathrm{c}$ & $9.17 \mathrm{~b}$ & $4.25 \mathrm{~b}$ \\
I00 & $51.44 \mathrm{a}$ & $14.66 \mathrm{a}$ & $6.03 \mathrm{a}$ \\
I50 & $45.05 \mathrm{~b}$ & $9.05 \mathrm{~b}$ & $4.34 \mathrm{~b}$ \\
LSD at $\alpha 0.05$ & 0.66 & 1.66 & 0.92 \\
Significance Level & Interaction (cultivars $\times$ GA) & & $*$ (Figure 3) \\
C $\times$ G & $*$ (Figure I) & $*$ (Figure 2) & \\
\hline
\end{tabular}

Means followed by the same letter (s) do not differ significantly from one another at $5 \%$ probability level, using LSD test.

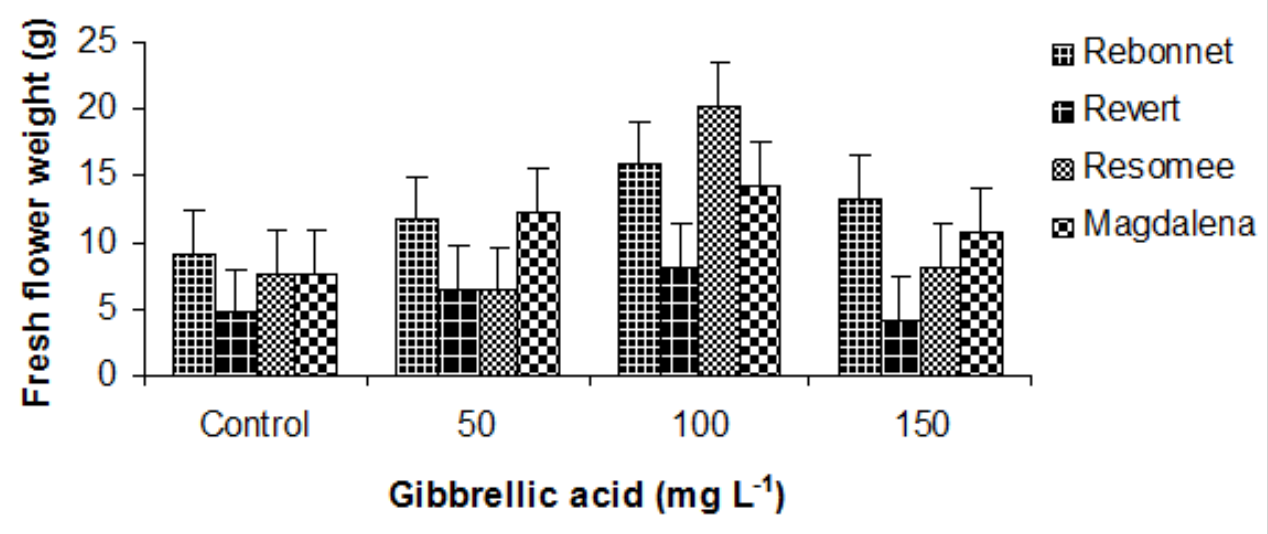

\section{Fig 2: Fresh flower weight (g) of chrysanthmum cultivars as affected by gibbrellic acid}

Figure 2 Fresh flower weights (g) of chrysanthemum cultivars as affected by gibbrellic acid. 


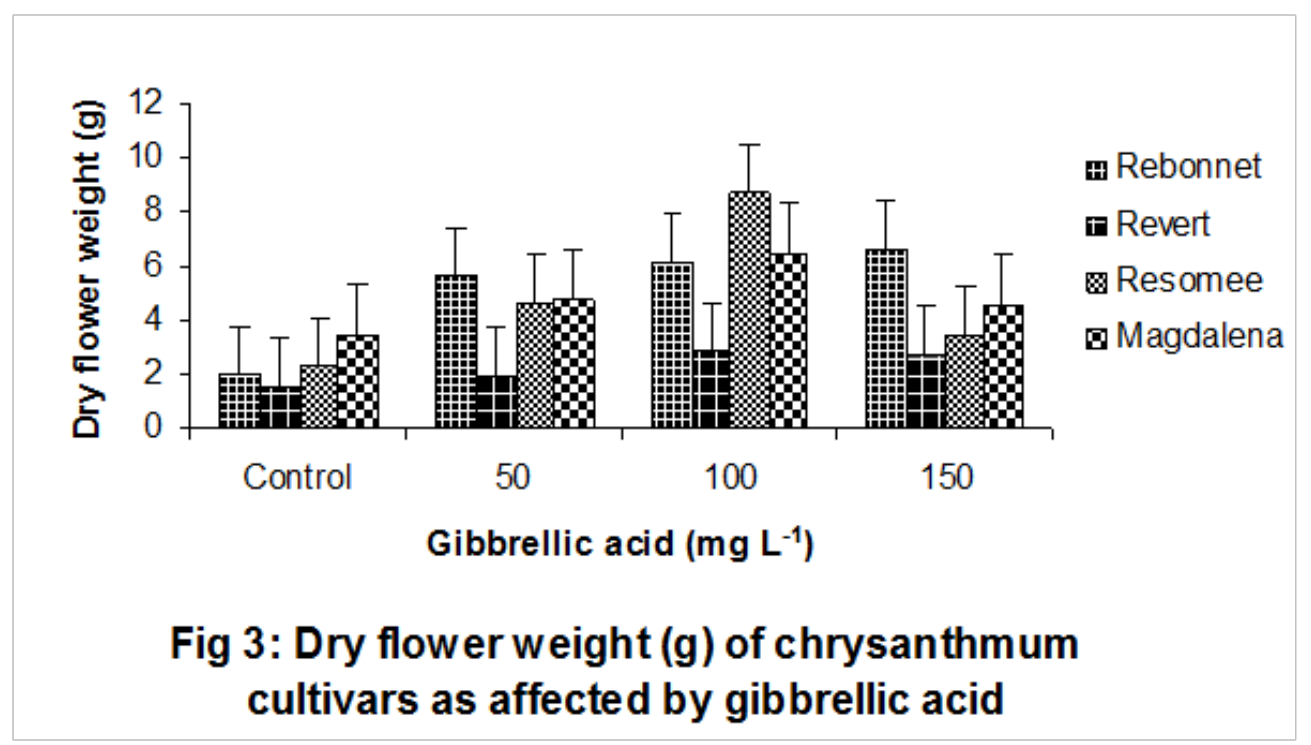

Figure 3 Dry flower weights (g) of chrysanthemum cultivars as affected by gibbrellic acid.

\section{Vase life (Days)}

The foliar application of gibbrellic acid $\left(\mathrm{GA}_{3}\right)$ and chrysanthemum cultivars had a significant effect on days to vase life of chrysanthemum cut flowers. While the interaction between foliar application of gibbrellic acid $\left(\mathrm{GA}_{3}\right)$ and chrysanthemum cultivars had a non significant effect on days to vase life of chrysanthemum cut flowers (Table 3). The mean value for vase life of different chrysanthemum cut flower cultivars indicated that the highest (30.08) days to vase life was recorded for the cultivar Rebonnet, followed by 28.19 days in cultivar Magdalena. Whereas, the lowest (27.43) vase life was recorded in cultivar Revert. The foliar application of gibbrellic acid $\left(\mathrm{GA}_{3}\right)$ had a significant effect on vase life of chrysanthemum cut flowers. The foliar application of gibbrellic acid $\left(\mathrm{GA}_{3}\right)$ at rate of $100 \mathrm{mgL}^{-1}$ on chrysanthemum plants increased the number of days (37.15) to vase life. The least days (23.91) to vase life was observed in plants grown under control condition. The increase in the post harvest flower life of cultivar Rebonnet might be linked to acquiring more sucrose from sugar solution in vases and became able to compete and retarded action of ethylene as compared to other chrysanthemum cultivars. The results are in line with Kofranek \& Halevy ${ }^{35}$ who reported that post harvest life of chrysanthemum was more better than rose when kept in vases containing sucrose in appropriate percentage. The vase life could be correlated with ethylene production which is inhibited by the foliar application of gibbrellic acid $\left(\mathrm{GA}_{3}\right)$, because it may had retarded the onset of senescence in whole cut inflorescence stalk by containing higher amount of RNA content. ${ }^{36}$ Bewley et al., ${ }^{37}$ also stated that gibbrellic acid $\left(\mathrm{GA}_{3}\right)$ performed special role in the maintenance and regulation of flower and extend the vase life. The present findings on vase life is related with the results of Skutnik et al. ${ }^{38}$ who found that plant growth regulator extend the inflorescence longevity. Also the sugar solution enhanced vase life of cut flower by providing sufficient amount of energy and respiration substrate through sucrose solution. The experimental findings are in agreement with the results of Ichimura \& Hiraya ${ }^{39}$ who found an extension in vase life of pea flower kept in sugar solution.

\section{Percent flower petal fading (\%)}

The mean data table showed that foliar application of gibbrellic acid $\left(\mathrm{GA}_{3}\right)$, chrysanthemum cultivars and their interaction had a significant effect on percent flower petal fading (Table 3 ). The percent flower petal fading was significantly influenced by different chrysanthemum cultivars. However, the maximum value for the percent flower petal fading $(12.05 \%)$ was occurred for cultivar Revert, followed by $11.95 \%$ in cultivar Resomee. Which were at par with each other. The least percent flower petal fading $(9.69 \%)$ was recorded in cultivar Rebonnet. A significant variation was observed in percent flower petal fading in relation to different levels of foliar application of gibbrellic acid $\left(\mathrm{GA}_{3}\right)$. The highest percent flower petal fading $(12.00 \%)$ was observed in control plants. Whereas, the least percent flower petal fading $(10.32 \%)$ was recorded in plants treated with foliar application of gibbrellic acid $\left(\mathrm{GA}_{3}\right)$ at the rate of $100 \mathrm{mgL}^{-1}$ As concerned interaction, the highest percent flower petal faded (13.93 $\%$ ) was observed in cultivar Resomee grown under control treatment. Whereas, the least percent flower petal faded $(8.21 \%)$ was recorded in chrysanthemum cultivars Rebonnet treated with $\mathrm{GA}_{3}$ at the rate of $100 \mathrm{mgL}^{-1}$ (Figure 4). The increase in the percent flower petal fading in cultivar Revert might be due to genetic makeup. It may also be due to less protein content and reserved food in petals and climate, humidity and temperature have affected the fading of petal in chrysanthemum cultivars. After evaluation of different chrysanthemum cultivars Carvalho et al., ${ }^{40}$ also found similar results and put forward the reason of high temperature and humidity as the factor of percent flower petal fading. The increase in percent flower petal fading of chrysanthemum cultivars might be due to the reason that the aging was rapid in inflorescence part not treated with foliar application of gibbrellic acid $\left(\mathrm{GA}_{3}\right)$ as compared to those cultivars treated with growth regulator. The present result had uniformity with the findings of Kim et al., ${ }^{41}$ who found that production of endogenous ethylene multiplied the synthesis of abcissic acid which caused early fading in the cut flower. According to Thingnaes et al. ${ }^{42}$ the variation in photoperiod may be regulate or deregulate the production of endogenous gibbrellin which directly or indirectly influenced percent fading. 


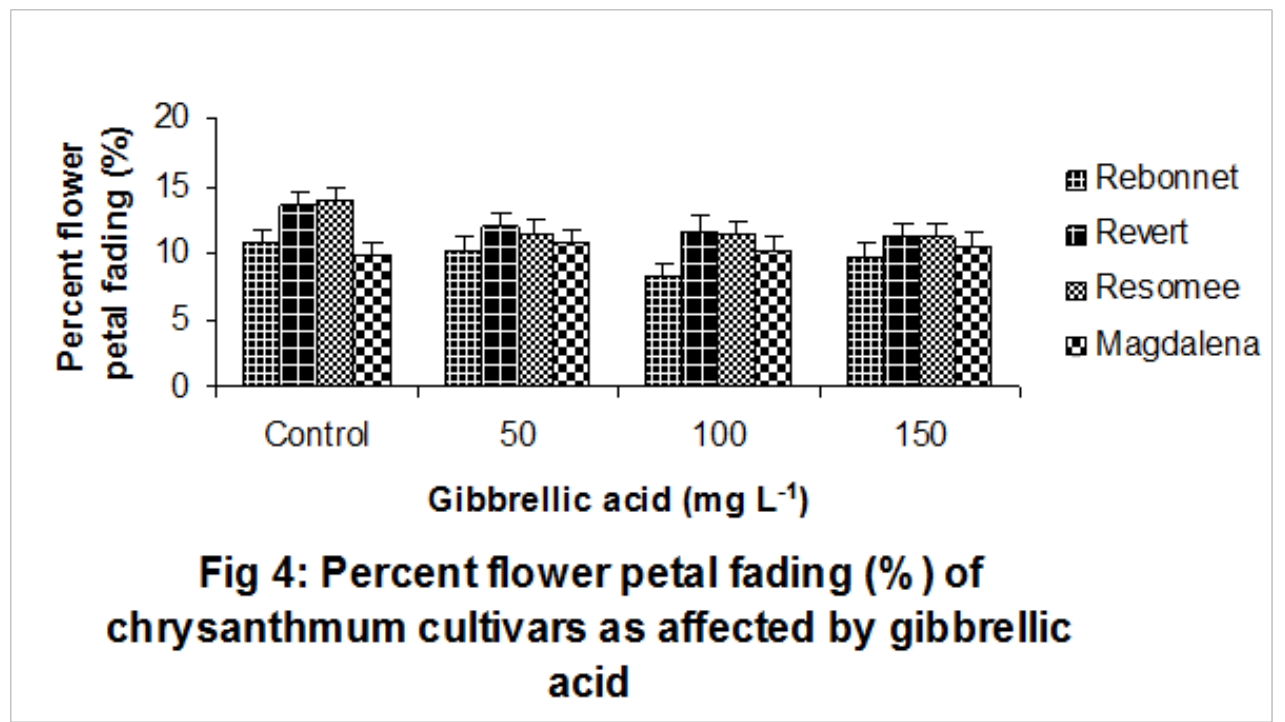

Figure4 Percent flower petal fading (\%) of chrysanthemum cultivars as affected by gibbrellic acid.

Table 3 Post harvest flower life, Percent flower petal fading (\%) of chrysanthemum cultivars as affected by gibbrellic acid $\left(\mathrm{GA}_{3}\right)$

\begin{tabular}{lll}
\hline Parameters & Vase life & $\begin{array}{l}\text { Percent flower } \\
\text { petal fading (\%) }\end{array}$ \\
\hline Cultivars & & \\
Rebonnet & $30.08 \mathrm{a}$ & $9.69 \mathrm{c}$ \\
Revert & $27.43 \mathrm{~b}$ & $12.05 \mathrm{a}$ \\
Resomee & $27.77 \mathrm{~b}$ & $11.95 \mathrm{a}$ \\
Magdalena & $28.19 \mathrm{~b}$ & $10.27 \mathrm{~b}$ \\
LSD at $\alpha 0.05$ & 0.85 & 0.52 \\
Gibbrellic acid concentration (mg L-1) & \\
Control & $23.91 \mathrm{c}$ & $12.00 \mathrm{a}$ \\
50 & $25.93 \mathrm{~b}$ & $11.07 \mathrm{~b}$ \\
I00 & $37.15 \mathrm{a}$ & $10.32 \mathrm{c}$ \\
I50 & $26.49 \mathrm{a}$ & $10.57 \mathrm{bc}$ \\
LSD at $\alpha 0.05$ & 0.85 & 0.52 \\
Significance Level & Interaction (cultivars $\times$ GA) \\
$\mathrm{C} \times \mathrm{G}$ & NS & $*($ Figure 4) \\
\hline
\end{tabular}

Means followed by the same letter (s) do not differ significantly from one another at $5 \%$ probability level, using LSD test.

\section{Conclusion and recommendations}

Based on the experimental results it is concluded that the different chrysanthemum cultivars significantly influenced most of the growth and flower parameters. Whereas, the cultivar "Rebonnet" resulted in highest quality flower production, while the cultivar Resomee resulted in the lowest quality flower. The foliar application of gibbrellic acid $\left(\mathrm{GA}_{3}\right)$ at the rate of $100 \mathrm{mg} \mathrm{L}^{-1}$ significantly affected the growth and quality flower production of chrysanthemum cultivars as compared to control plants. It was concluded that the cut flower production at commercial scale by using foliar application of gibbrellic acid $\left(\mathrm{GA}_{3}\right)$ is not as much expensive as the local community thinking but it is economical and most beneficial to get quality cut flowers. The chrysanthemum cultivar Rebonnet when treated with $100 \mathrm{mgL}^{-1}$ of foliar application of gibbrellic acid $\left(\mathrm{GA}_{3}\right)$ resulted in best quality flower production under the agro climatic condition of PeshawarPakistan.

\section{Acknowledgements}

None.

\section{Conflict of interest}

Authors declare that there is no conflict of interest.

\section{References}

1. Arora JS. Introductory Ornamental Horticulture. Kalyani Publishers. New Delhi: 1990;48.

2. Liu DH, Liu W, Zhu DW, et al. Nitrogen effects on total flavonoids, chlorogenic acid, and antioxidant activity of the medicinal plant Chrysanthemum morifolium. J Plant Nutr Soil Sci. 2010;173:268-274.

3. Teixeira da Silva JA. Ornamental chrysanthemums improvement by biotechnology. Plant Cell Tissue and Organ Culture. 2004;79(1):1-18.

4. Boran, S. Overview to Cut Flower Sector. Izmir Chamber of Commerce AR \& GE Bulletin; Turkey: 2008.

5. Kim, Yun T. Effect of shading and mulching on growth and flower quality of chrysanthemums. J Korean Soc Hort Sci. 2000;41:631-635.

6. Kher MA. Chrysanthemum Queen of the East. Indian Hort., 1990;35(1):10-13.

7. Abo EE, Behairy $\mathrm{ZH}$, Ahmed MA. Bunch weight and fruit quality smani date palm (Phoenix dactylifera $\mathrm{L}$.) as affected by some growth regulators. J Agric Sci Mansoura. 2002;27(1):517-524. 
8. Figueroa I, Colinas MT, Mejia J, et al. Postharvest physiological changes in roses of different vase life. Ciencia Investigation Agraria. 2005;32:167-176.

9. Ichimura KR, Goto K. Extension of vase life of cut Narcissus tazetta var. chinensis flowers by combined treatment with STS and Gibberellin $\mathrm{A}_{3}$. J Society for Horti Sci. 2002;71:226-230.

10. Taiz L, Zeiger. Effect of $\mathrm{GA}_{3}$ on height and induction of flowers in ornamental plants. Fisiologia vegetal. 2004;3:720.

11. Khan MR, Qureshi AF, Hussain SA, et al. Genetic variability induced by gamma irradiation and its modulation with gibbrellic acid in $\mathrm{M}_{2}$ generation of chickpea (Cicer arietinum). Pak J Bot. 2005;37(2):285292.

12. Hunter $\mathrm{M}, \mathrm{X} \mathrm{Xu}$, Ried T. Role of ethylene in perianth senescence of daffodil (Narcissus pseudonarcissus L. 'Dutch Master'). Postharvest Bio Tech. 2004;32(3): 269-280.

13. Saifuddin M, Hossain ABMS, Normaniza O, et al. The effects of naphthaleneacetic acid and gibberellic acid in prolonging bract longevity and delaying discoloration of Bougainvillea apectabilis. Biotech. 2009;8(3):343-350.

14. Steel RGD, Torrie JH, Dickey DA. Principles and procedures of statistics. A biometrical approach; McGrew-Hill publishing: 1997.

15. Arun DS, Ashok AD. Rengasamy P. Effect of some growth regulating chemicals on growth and flowering of rose "First red" under Greenhouse Conditions. J Ornam Hort. New Series, 2000;3(1):51-53.

16. Dorajeerao LK, Mokashi AN. Effect of pre-harvest application of growth regulator on vase life of Garland chrysanthemum. Plant Archives. 2011;293-295.

17. Abadi DH. Effect of different concentrations of Salycilic acid on growth and flowering of Rosa Hybrida. Proceeding of 6 Iranian Horticultural Science Congress; Iran: 2010;345.

18. Davies BD. Plant hormones physiology, biochemistry and molecular biology. Kluwer Academic Publishers; Netherlands: 1995.

19. Blazquez M. Trenor D. Weigel. Independent control of gibberellins biosynthesis and flowering time by the circadian clock in Arabidopsis. Bethesda Plant Physiol. 2002;130:1771-1775.

20. Paroussi G, Voyatzis DG, Parroussi E, et al. Growth, flowering and yield responses to GA3 of strawberry grown under different environmental conditions. Amsterdam Sci Hort. 2002;96(1-4):103-113.

21. Pharis RP, King RW. Gibberellins and reproductive development in seed plants. Plant Physiol. 1985;36:517-568.

22. Rakesh, Singhrot RS, Beniwal BS. Effect of $\mathrm{GA}_{3}$ and pinching on growth and yield in chrysanthemum. South Indian Hort. 2003;32(1/2):61-63.

23. Madhumita CT, Paswan L. Effect of $\mathrm{GA}_{3}$ and $\mathrm{CCC}$ on growth and flowering of standard chrysanthemums. J Oran Hort. 1998;1(1):11-16.

24. Maximos SEA, Aziz BA, Desouky IM, et al. Effect of $\mathrm{GA}_{3}$ and ethephon on the yield and quality of Seewy date fruits. Annals of Agric Sci Moshtohor: 1980;12:251-262.

25. Ma ZY, Shimizu H, Moriizumi S, et al. Effect of light intensity, quality and photoperiod on stem elongation of chrysanthemum cv. reagan. Environ Control Biol. 2007;45(1):19-25.
26. Khan A, Chaudhry NY. GA 3 improves flower yield in some cucurbits treated with lead and mercury. J Biotech. 2006;5(2):149-153.

27. Halevy M, Mayak S. Senescence and postharvest physiology of cut flowers. Part 2. Hort Rev. 1981;3:59-143.

28. Cowan M, Freeman P, Bjorkman B, et al. Effects of senescence induced alteration in cytokinin metabolism on source-sink relationships ontogenic and stress induced transitions in tobacco. Planta. 2005;221(6):801-814.

29. Hicklenton PR. Influence of different levels and timing of supplemental irradiation on pot chrysanthemum production. HortSci. 1985;20:374 376

30. Aziz ABA, Maximous SS, Desouky IA. et al. Effect of $\mathrm{GA}_{3}$ and hand pollination on the yield and quality of Sewy dates. Botany Laboratory; Egypt: 1982.

31. Kumar R, Singh K. Effect of Growth Regulator and Shoot Tip Pinching on Carnation. J Orn Hort. New Series. 2003;6(2):134-136.

32. Onozaki T, Ikeda H, Yamaguchi T. Genetic improvement of vase life of carnation flowers by crossing and selection. Sci Hort. 2001;87(12):107-120

33. El Hodairi, El Barkouli, Baula O. The effects of some growth regulators on fruit set of date palm (Phoenix dactylifera L.) trees. In International Symposium on tropical fruit frontier in tropical fruit research. Acta Hort 321. 1991;334-342.

34. Ambad IB, Kadam AL. Effect of different planting dates on the Pyrethrum flower. J Maharashtra Agric Univ. 1998;23:66-67.

35. Kofranek A. Halev A. Condition for opening cut Chrysanthemum flower buds. J Amer Hort Sci. 1972;97:578-584.

36. Dahale, MH, Deshmukh PP, Moharkar VK. Influence of foliar application of $\mathrm{GA}_{3}$ on quality of chrysanthemum. J Soils and Crops. 1993;3(2):135-137.

37. Bewley JD, Hempel FD, McCormick S. Role of molecules like gibbrellin, auxin and cytokinin in reproductive development of plant. Mol Biol Plants. 2000;988:1043.

38. Skutnik E, Rabiza J, Lukaszewska AJ. Evaluation of several chemical agents for prolonging vase life in cut asparagus greens. J Fruit Ornament Plant Res. 2006;14:233-240.

39. Ichimura KH. Effect of silver thiosulphates complex (STS) in combination with sucrose on the vase life of cut sweet pea flowers. Hort Sci. 1999;68(1):23-7.

40. Carvalho MPS, Abi Tarabay H, Heuve link E. Temperature affects chrysanthemum flower characteristics differently during three phases of the cultivation period. J Hort Sci Biotechnol. 2005;80(2):209-216.

41. Kim HJ, Craig R, Brown MR. Genetically enhanced postproduction in quality regal pelargonium. Acta Horti. 2005;669:135-2.

42. Thingnaes E, Torre S, Ernstsen A, et al. Effects of gibberellin and auxin on contents of cell size, morphology and flowering time. London Ann Bot. 2003;92(4):601-612. 